\title{
PROPERTIES OF THERMALLY MODIFIED TEAKWOOD
}

\author{
Elaine Cristina Lengowski, ${ }^{1, \mathrm{~s}}$ \\ https://orcid.org/0000-0002-7336-7626 \\ Eraldo Antonio Bonfatti Júnior ${ }^{2}$ \\ https://orcid.org/0000-0002-2730-7681 \\ Silvana Nisgoski ${ }^{2}$ \\ https://orcid.org/0000-0001-9595-9131 \\ Graciela Inês Bolzon de Muñiz² \\ https://orcid.org/0000-0003-4417-0178 \\ Umberto Klock ${ }^{2}$ \\ https://orcid.org/0000-0003-3946-3320
}

\begin{abstract}
Thermal modification is a treatment that seeks to improve the properties of wood and reduce the heterogeneity in its color. The objective of this work was to evaluate the effect of thermal treatment on the anatomical, chemical, physical, mechanical, colorimetric, and thermal stability properties of teakwood. For this, teakwood samples were treated by an industrial autoclave at final cycle temperature of $160^{\circ} \mathrm{C}$. The reduction of cell wall thickness, the formation of cross-fissures and the crystallization of the wax inside the pores were observed in the anatomical structure. Chemically, the extractives evaporated and the polysaccharides ruptured, of which hemicellulose was the most affected. The heat treatment promoted lower equilibrium moisture, reducing the hygroscopicity and improving the dimensional stability of the wood. Considering the mechanical properties, the rupture modulus and the longitudinal and tangential hardness decreased after the heat treatment. The color of the wood changed significantly, from pink to dark brown. The treated wood had higher thermal stability, with greater weight loss at higher temperatures than the untreated wood.
\end{abstract}

Keywords: Colorimetry, cell wall thickness, thermogravimetry, Tectona grandis, wood properties, wood mechanical properties, wood hygroscopicity, wood modification. 


\section{INTRODUCTION}

Tectona grandis, commonly known as teak, grows naturally in Southeast Asia and is one of the most valuable tropical species in the international market (Niamké et al. 2011, Nocetti et al. 2011, Niamké et al. 2014, Pratiwi et al. 2019). Besides its natural occurrence, teak is planted in many tropical regions of the Americas and Africa (Kokutse et al. 2004). In Brazil, there are approximately 93,957 hectares planted of teak (IBÁ 2019), and mostly are concentrated mostly in Midwest, especially in the state of Mato Grosso (FAMATO 2013).

Teakwood is appreciated for its moderate basic density, high mechanical strength, texture, aesthetics, color, workability, dimensional stability, and natural durability (Kokutse et al. 2006, Derkyi et al. 2009). It can be used for many purposes, both internal and external, including home building, shipbuilding, furniture manufacture, poles, and sculptures (Niamké et al. 2011, Niamké et al. 2014).

Teakwood is porous with distinct growth rings marked by lines of marginal parenchyma, and its sapwood has a yellowish color and brown heartwood. The quality of teak wood is mainly linked to the heartwood region (Lemos et al. 2019), since high natural durability and high dimensional stability, characteristics due to the presence of some substances, such as caucho, a species of latex responsible for the reduction water absorption, and tectoquinone, a natural preservative contained in the cells of the wood (Kokutse et al. 2006).

In the T. grandis species, the sapwood presents inferior wood quality than heartwood (Lemos et al. 2019), the heterogeneous and yellowish color pattern in the sapwood reduces its acceptance in the market (Mononen et al. 2002). As a solution, it is common to apply heat treatment in teakwood to reduce the differences observed in coloring (Bonfatti Júnior and Lengowski 2018).

The modification of wood consists of processes to improve its properties, producing a new material. In this context, thermal modification stands out: since it does not use any chemicals, it does not present a greater environmental liability than wood without thermal modification (Hill 2006).

The thermal modification of wood is conducted using controlled heating at relatively high temperatures of $150{ }^{\circ} \mathrm{C}$ to $260^{\circ} \mathrm{C}$ (Grinins et al. 2016). This treatment is used to improve dimensional stability, reduce hygroscopicity, and modify and standardize staining. However, as adverse result in wood, the mechanical properties decrease (Esteves and Pereira 2009), flammability increases (Čekovská et al. 2017), mass is lost (Esteves and Pereira 2009) and chemical components are modified and broken (Weiland and Guyonnet 2003, Shi et al.2018).

To understand the effects of thermal modification technique beyond color changes, this article compares the anatomical, chemical, physical, mechanical, colorimetric, and thermal stability properties of thermally treated teakwood with the characteristics of the untreated teakwood.

\section{MATERIAL AND METHODS}

\section{Wood}

Boards of teakwood (Tectona grandis L. f.), untreated and thermally treated, were donated by TW Brazil company, the wood came from 25-years-old commercial plantations in Mato Grosso state, but the heat treatment station is in Ponta Grossa, Paraná state, Brazil. The thermal modification was performed by the VAP HolzSysteme ${ }^{\circledR}$ process, applying heat of $160{ }^{\circ} \mathrm{C}$ in a saturated steam atmosphere with efficient elimination of oxygen. The treatment was performed in five stages: an initial heating ramp with duration up to constant temperature $\left(110^{\circ} \mathrm{C}\right), 25$ minutes at this temperature; a second ramp with duration until the final temperature $\left(160{ }^{\circ} \mathrm{C}\right) ; 45$ minutes at maximum temperature; and natural cooling. The total duration of the process was about 16 hours, carried out in two 8-hours heating-cooling cycles, with mass loss not exceeding $12 \%$. Five boards per treatment were analyzed. 


\section{Anatomical and surface analysis}

For the general description of the anatomical characteristics, samples with dimensions of $1,5 \mathrm{~cm} \times 1,5 \mathrm{~cm} \mathrm{x}$ $2,0 \mathrm{~cm}$ were collected from the boards. These samples were submitted to boiling for softening and then histological sections in the transverse, tangential and radial directions were cut in a sliding microtome, with a thickness of $28 \mu \mathrm{m}$. The anatomical description of the wood, following the standards established by International Association of Wood Anatomists (Wheeler et al.1989), was carried out with an Olympus CX 40 microscope (Tokyo, Japan, Olympus Corporation).

Scanning electron microscopy (SEM) was used for surface description of the untreated and thermally modified samples, with a PHILIPS XL-30 microscope after the samples were covered with a thin layer of gold in a vacuum chamber.

\section{Chemical constituents}

The wood sampling and preparation for chemical analysis were carried out in accordance with the Technical Association of the Pulp and Paper Industry T 257 sp-14 standard (TAPPI 2014) in three samples per treatment. At this point we determined total extractive content following T $204 \mathrm{~cm}-17$ standard (TAPPI 2017) and insoluble lignin content following T $222 \mathrm{om}-15$ standard (TAPPI 2015). Holocellulose content was calculated by Equation 1.

Holocellulose content $=100-$ total extractive content - insoluble lignin content

\section{Physical and mechanical properties}

The wood's basic density was determined in accordance with ASTMD-2395-17 (2017). To analyze the effect of the thermal modification on the dimensional stability, the radial, tangential and volumetric shrinkage were tested following ASTM D-143-14 (2014), and the anisotropy of shrinkage was calculated by the ratio of tangential shrinkage divided by radial shrinkage.

The wood samples were air-conditioned in a climatic chamber with $12 \%$ relative air humidity. After this, the moisture was determined following ASTM D-143-14 (2014) and the result was used as a measure of hygroscopicity of untreated and thermally modified wood.

Finally, to analyze the effect on the mechanical properties, static bending and hardness (longitudinal, radial and tangential) were tested following ASTM D-143-14(2014).

\section{Color measurements}

Wood color was measured with a Konica Minolta CM-5 spectrophotometer coupled to a computer, with adjustment to a D65 light source and $10^{\circ}$ observation angle. The reflectance data were obtained with a spectral range from $400 \mathrm{~nm}$ to $750 \mathrm{~nm}$. Ten spectra were collected per board, directly on the radial/tangential surface. A total of 200 spectra were obtained, 50 for each treatment, and analysis was performed of all spectra.

The following color parameters were measured and calculated, following the ASTM D-2244-16 (2016): lightness $\left(\mathrm{L}^{*}\right)$, green-red coordinate $\left(\mathrm{a}^{*}\right)$, blue-yellow coordinate $\left(\mathrm{b}^{*}\right)$, color saturation $\left(\mathrm{C}^{*}\right)$, hue angle $(\mathrm{h})$ and the color difference between the two kinds of produced pulps $(\Delta \mathrm{E})$.

\section{Thermal analysis}

The thermogravimetric characterization (TGA) was performed with a Netzsch TGA 209 under $\mathrm{N}_{2}$ atmosphere with a heating rate of $20^{\circ} \mathrm{C} \cdot \mathrm{min}^{-1}$ to maximum temperature of $900{ }^{\circ} \mathrm{C}$. 


\section{Statistical analysis}

Analysis of variance (ANOVA) was applied to identify differences between natural and thermally modified wood. The significance level $(\alpha)$ was $5 \%$, considering the null hypothesis $(\mathrm{H} 0)$ of equivalence between the means and alternative hypothesis (H1) of non-equivalence. F-critical greater than the F value involves accepting H0, rejecting it otherwise. To validate the ANOVA model, Shapiro-Wilk and the Bartlett's tests were used to verify the normality of the distribution and the homogeneity between variances, respectively, both at $5 \%$ significance.

\section{RESULTS AND DISCUSSION}

\section{Anatomical and surface analysis}

Teakwood presented distinct growth rings. The rings were porous, with numerous large pores in the initial zone of the growth layers, with simple perforation plates and alternate intervessel pits. Tyloses, gums and other deposits were present in heartwood vessels. Fibers had simple, septate and non-septate scoring. The axial parenchyma was composed of marginal or seemingly marginal vasicentric bands. All cells of the rays were procumbent, with presence of silica (Figure 1).
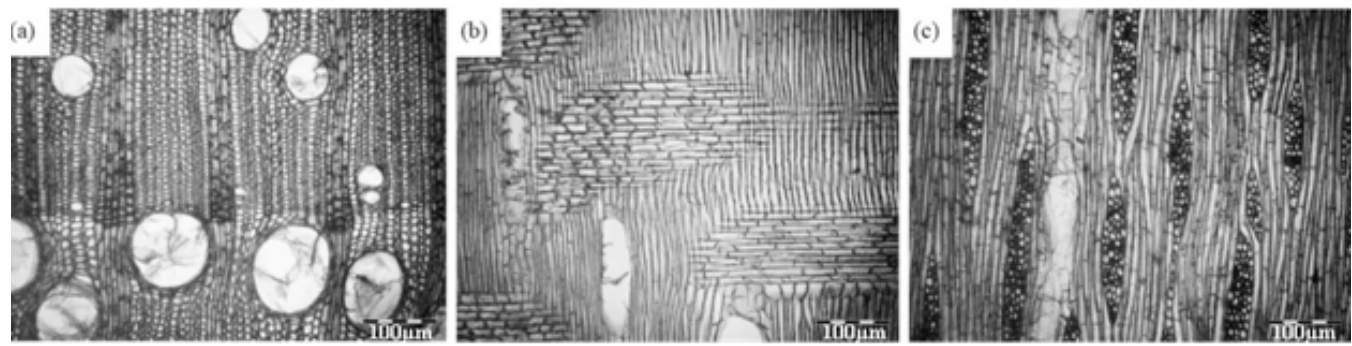

Figure 1: Microscopic photos of the anatomical aspects of teakwood. (a) = Transversal section; (b) = Radial section; (c) = Tangential section.

The anatomical structure of the wood did not change significantly (Figure 2). There was a decrease in the thickness of the walls and the formation of cracks in the cross section (Figure 2b). In the radial section, the presence of the substances inside the crystallized pores can be observed in the treated wood (Figure 2d).

There was formation of many cracks due to the rupture of the wall and breaking of links between fibrils. These cracks result from the high vapor pressure generated by resistance to water movement when the wood is subjected to heating, since this species has pores obstructed by gums and tyloses. Cell walls ruptured perpendicular to the direction of the fiber, resulting in transverse ruptures and contributing to the abrupt fracture in bending tests of treated wood (Boonstra et al.2006a). 

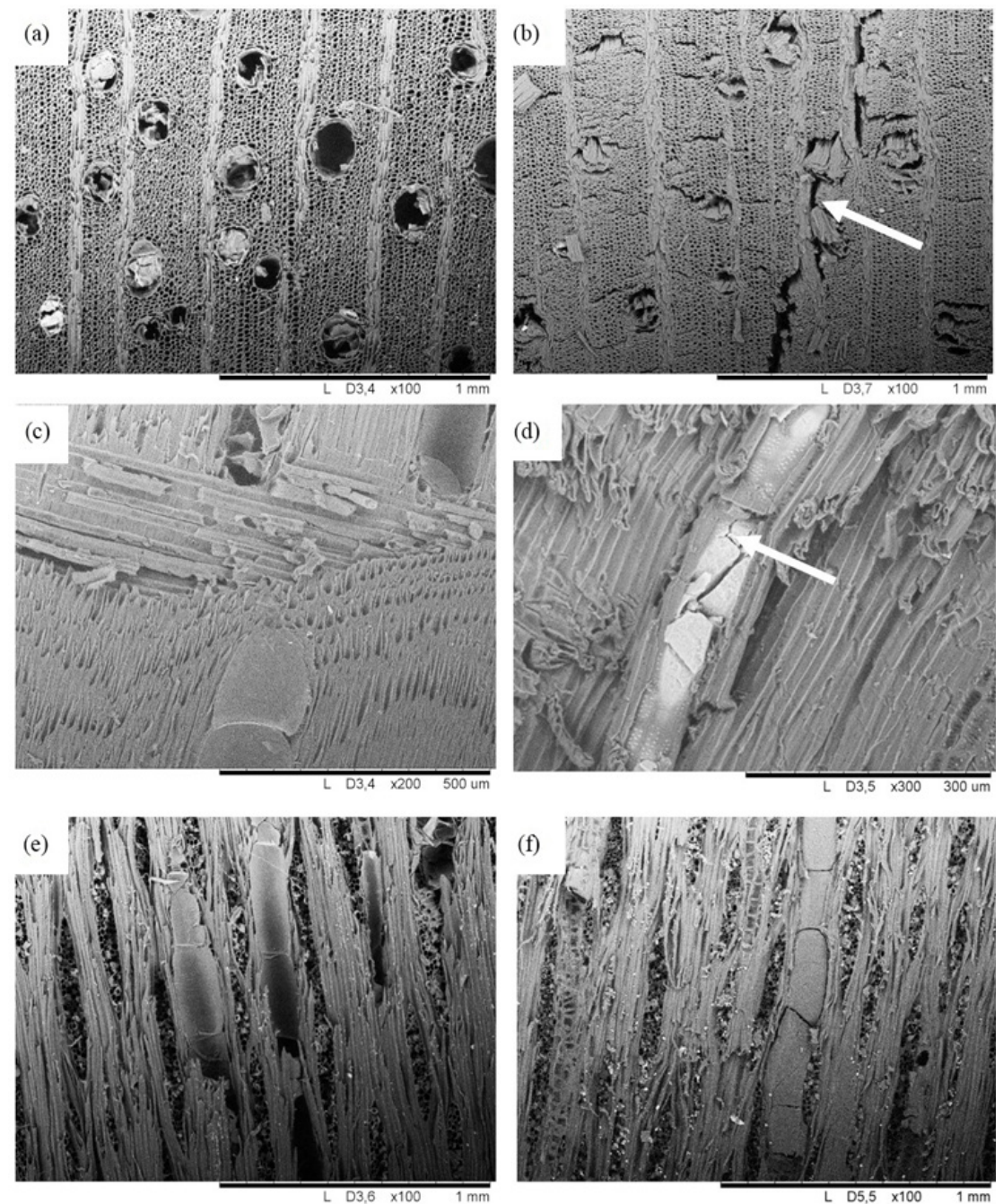

Figure 2: Scanning electron microscopy images of the morphological aspects before and after treatment of teakwood. (a) = Transverse section of the wood without heat treatment; (b) = Transverse section of wood with heat treatment; (c) = Radial section of the wood without heat treatment; $(d)=$ Radial section of wood with heat treatment; (e) = Tangential section of the wood without heat treatment; (f) = Tangential section of wood with heat treatment.

Anatomically, the modifications depend on the conditions of the process used and the peculiarities of the species (Esteves and Pereira 2009, Boonstra et al.2006a, Shiet al.2018). When heat treating Picea abies between $180{ }^{\circ} \mathrm{C}$ to $200{ }^{\circ} \mathrm{C}$, Fengel (1966) found cracks in the middle lamella and layer S1, and visible changes in the walls, as well as dissolved substances deposited in the cell cavities. In turn, Boonstra et al.(2006b), studying the thermal treatment of hardwoods, concluded that Populus sp. was sensitive to vessel collapse and to some deformations in the libriform fibers near the vessels, Betula sp. Wood presented some radial cracks, and Fagus sp. wood presented the two types of mentioned damage. 


\section{Chemical constituents}

The thermal treatment altered the chemical composition of the wood significantly, degrading extractive and cell wall compounds. The total extractives content and insoluble lignin content were greater in the treated teakwood, but the thermal treatment caused a drop in holocellulose content (Table 1).

Table 1: Chemical constituents of wood samples.

\begin{tabular}{|c|c|c|c|}
\hline Treatment & Total extractives (\%) & Insoluble lignin (\%) & Holocellulose (\%) \\
\hline UTW & $11,03 *(11,22)$ & $25,75 *(17,98)$ & $61,22 *(9,89)$ \\
\hline TTW & $16,39 *(28,48)$ & $32,56 *(9,80)$ & $49,07 *(14,48)$ \\
\hline
\end{tabular}

$\mathrm{UTM}=$ untreated teakwood; TTU $=$ treated teakwood; $\mathrm{ns}=$ no significant difference by the F-test at $5 \%$ confidence;

* significant difference by the F-test at $5 \%$ confidence. Values between parentheses are the coefficients of variation of the samples.

When analyzing the chemical constituents of the teakwood Chagas et al. (2014) and Pratiwi et al. (2019) found lower extractives content $(4,76 \%$ and $7,41 \%)$, higher insoluble lignin content $(30,43 \%$ and $32,57 \%)$ and holocellulose content $(64,01 \%$ and $67,42 \%)$ to the values of the untreated teakwood in the present study.

After the heat treatment at $220{ }^{\circ} \mathrm{C}$ for $20 \mathrm{~h}$ Pratiwi et al. (2019) found a mean holocellulose reduction of $15,18 \%$ and total extractives of $21,32 \%$, while an increase in lignin content of $31,3 \%$ occurred. While in this work an increase in total extractive content $(48,59 \%)$ and lignin $(26,44 \%)$ and a reduction in holocellulose content of $19,84 \%$ were found. Chemical changes due to heating depend on the duration, temperature and type of the treatment, with temperature being the main factor (Esteves and Pereira 2009). Lengowski et al. (2018), studying the wood of Pinus taeda and Eucalyptus grandis, observed an increase in extractives content and reduction of holocellulose content for both species, but only for $E$. grandis was there a significant increase in lignin content.

The most extractives disappear or degrade during the heat treatment, especially the more volatile ones. However, due to degradation of the structural components of the cell walls, new compounds that can be extracted from the wood are created, causing the extractives content to increase substantially with the loss of weight (Esteves et al. 2008, Esteves and Pereira 2009).

Hemicellulose is the most affected fraction due to its amorphous structure and low molecular weight (Poncsák et al. 2006, Hamada et al. 2017, Shiet al. 2018), thus responsible for the drop in holocellulose content. Degradation of the hemicelluloses begins by deacetylation, and the resulting formation of acetic acid acts as a catalyst for depolymerization, further increasing the polymer breakdown, leading to the formation of formaldehyde, furfural and other aldehydes (Nuopponen et al. 2005). The degradation of pentoses and hexoses formed the furfural and hydroxymethylfurfural products (Nuopponen et al. 2005). At the same time as these reactions occur, the hemicelluloses undergo dehydration reactions, with decrease of the hydroxyl groups (Weiland and Guyonnet 2003).

The loss in resistance of the cell wall observed in Figure $2 \mathrm{~b}$ may also have occurred due to the elimination of part of the hemicellulose, which acts as a binding element between cellulose and lignin.

Cellulose is less affected by thermal treatments, probably due to its semi-crystalline nature (Esteves and Pereira 2009). However, as the temperature increases, the amorphous regions are degraded (Lengowski et al. 2013), causing an increase in the cellulose crystallinity, which decreases in the accessibility to hydroxyl groups by water molecules (Bhuiyan and Hirai 2005, Boonstra and Tjeerdsma 2006). This may be one of the causes of the reduction of the equilibrium moisture content.

The percentage increase of lignin occurs because this polymer degrades at temperatures higher than the polysaccharides (Esteves et al. 2008). The cleavage of the ether linkages, especially $\beta-O-4$, leads to the formation of free phenolic hydroxyl groups and $\alpha$ - and $\beta$-carbonyl groups (Nuopponen et al. 2005), which are 
responsible for crosslinking through the formation of methyl groups (Nuopponen et al. 2005, Tjeerdsma and Militz 2005). With the reduction of the methoxyl content, new reactive regions in the aromatic ring can lead to new condensation reactions (Wikberg and Maunu 2004).

\section{Physical and mechanical analysis}

For equilibrium moisture with the environment, a significant drop was observed after the heat treatment. No significant variation was observed in the physical properties of basic density, longitudinal contraction, and radial contraction after thermal modification. However, the equilibrium moisture, volumetric contraction, tangential contraction and contraction anisotropy were reduced (Table 2).

Table 2: Physical properties of wood.

\begin{tabular}{|c|c|c|c|c|c|c|c|}
\hline Treatment & SG $\left(\mathrm{kg} \mathrm{m}^{-3}\right)$ & EM (\%) & VS (\%) & LS (\%) & RS (\%) & TS (\%) & AS \\
\hline \multirow{2}{*}{ UTW } & $480^{\text {ns }}$ & $15,21^{*}$ & $6,07^{*}$ & $0,71^{\text {ns }}$ & $1,89^{\text {ns }}$ & $3,57^{*}$ & $1,88^{*}$ \\
& $(1,15)$ & $(1,84)$ & $(9,19)$ & $(9,19)$ & $(9,23)$ & $(9,99)$ & $(3,22)$ \\
\hline \multirow{2}{*}{ TTW } & $470^{\text {ns }}$ & $8,76^{*}$ & $4,22^{*}$ & $0,53^{\text {ns }}$ & $1,73^{\text {ns }}$ & $2,01^{*}$ & $1,15^{*}$ \\
& $(1,24)$ & $(2,87)$ & $(8,81)$ & $(8,81)$ & $(7,48)$ & $(17,77)$ & $(15,7)$ \\
\hline
\end{tabular}

$\mathrm{UTM}=$ untreated teakwood; TTU = untreated teakwood; $\mathrm{SG}=$ specific gravity; $\mathrm{EM}=$ equilibrium moisture; VS = volumetric shrinkage; LS = longitudinal shrinkage; $\mathrm{RS}=$ radial shrinkage; $\mathrm{TS}=$ tangential shrinkage; $\mathrm{AC}=$ anisotropy of shrinkage; $\mathrm{ns}=$ no significant difference by the F-test at $5 \%$ confidence; * significant difference by the F-test at $5 \%$ confidence. Values between parentheses are the coefficients of variation of the samples.

According to Lima et al. (2009) and Motta et al. (2010), the average density values of teakwood are between $670 \mathrm{~kg} / \mathrm{m}^{3}$ to $550 \mathrm{~kg} / \mathrm{m}^{3}$. Moya et al. (2009) found a wide variation for density of this species in different years, ranging from $550 \mathrm{~kg} / \mathrm{m}^{-3}$ to $875 \mathrm{~kg} / \mathrm{m}^{3}$. Our results are below the values mentioned above, but they are in line with those reported by Gonçalvez et al. (2007), who found values for teakwood of Brazilian origin between $400 \mathrm{~kg} / \mathrm{m}^{3}$ to $470 \mathrm{~kg} / \mathrm{m}^{3}$.

A reduction of the basic density of the wood is usually observed after heat treatment (Boonstra et al. 2007, Korkut 2008, Esteves and Pereira 2009, Ozsahin and Murat 2017). This was not observed for teakwood under our treatment conditions, since there was no significant difference in the basic density of treated and untreated wood.

Because it is an organic material, wood tends to absorb water and balance with the moisture of the environment. As the water vapor occupies the empty spaces between the cells of the wood, causing the dimensions of the cell walls to increase, and as a consequence the wood increases in dimension. These changes in dimension are anisotropic and are greatest in the tangential direction than radial direction, and least in the longitudinal direction (Hill 2006).

The reduction of equilibrium moisture was $42,40 \%$ in relation to wood without treatment. The reason for the decrease in equilibrium moisture is that less water is absorbed by the cell walls after the heat treatment, as a result of the decrease of the hydroxyl groups present in the hemicelluloses and in the amorphous regions of the cellulose. The inaccessibility of hydroxyl groups occurs due to increased crystallinity of cellulose with the heat treatment (Wikberg and Maunu 2004, Bhuiyan and Hirai 2005, Boonstra and Tjeerdsma 2006) and consequent decrease in the wood hydrophilic carbohydrates (Santos et al. 2014). This fact was demonstrated by Lengowski et al. (2013) who found, while modifying the cellulose crystallinity, that treatments with higher temperatures caused an increase in the crystalline index, indicating the removal of amorphous regions that are highly hygroscopic. The decrease in equilibrium moisture is also influenced by polycondensation and lignin crosslinking reactions (Repellin and Guyonnet 2005, Tjeerdsma and Militz 2005, Boonstra and Tjeerdsma 2006, Esteves et al. 2008).

The mean values for volumetric contraction of teakwood range from $6,31 \%$ to $5,23 \% ; 0,34 \%$ for longitudinal contraction, $1,75 \%$ to $1,88 \%$ for radial contraction, and 3,49 \% to $4,25 \%$ for tangential contraction, while the anisotropy coefficient is on the order of 1,99 to 2,27 (Bonduelle et al. 2015, Dias et al. 2018). The contractions found in the present work are close to those reported in the literature, but the anisotropy coefficient 
is higher.

There was a significant variation in the tangential contraction, causing a reduction of $77,86 \%$. The most important index to evaluate the dimensional stability of wood is the coefficient of anisotropy, defined as the ratio between tangential and radial contractions (RS/TS) (Durlo and Marchiori 1992). According to those authors' classification, the anisotropy coefficient of the untreated wood was normal wood $(1,5 \leq \mathrm{AC} \leq 2,0)$ and wood after heat treatment has excellent workability $(1,2 \leq \mathrm{AC}<1,5)$.

The increase in dimensional stability of thermally treated wood is due to the decrease in the hygroscopicity because of the chemical changes that occur. Tjeerdsma et al. (1998) observed that one of the probable reasons for the improvement of the dimensional stability is the loss of the methyl radicals of the guaiacyl and syringyl units of lignin, which leads to an increase in the proportion of phenolic groups. These chemical changes lead to greater reactivity of lignin, with the formation of several crosslinks, responsible for increasing dimensional stability. As the crosslinking increases, the molecule becomes less elastic and the cellulose microfibrils have less possibility to expand and absorb water, which explains the decrease in the equilibrium moisture and the improvement in the dimensional stability.

Not all mechanical properties were influenced by the heat treatment. For MOR, there was a significant drop in the property, from 69,39 MPa to $32,31 \mathrm{MPa}$, whereas there was no statistical difference in MOE. For longitudinal and tangential hardness, significant declines were observed, while in the radial direction this property did not change significantly (Table 3 ).

The mechanical properties most affected by the heat treatment are MOR in flexural strength and impact flexion tests (Esteves and Pereira 2009). The reduction of these properties is related to the changes in the chemical structures of the wood (Yildiz et al. 2005). However, thermal treatments can increase the modulus of elasticity (Esteves and Pereira 2009).

Table 3: Mechanical properties of wood.

\begin{tabular}{|c|c|c|c|c|c|}
\hline \multirow{2}{*}{ Treatment } & \multicolumn{2}{|c|}{ Static bending (MPa) } & \multicolumn{3}{c|}{ Hardness (N) } \\
\cline { 2 - 6 } & MOR & MOE & Longitudinal & Radial & Tangential \\
\hline \multirow{2}{*}{ UTW } & $69,39^{*}$ & $7202,17^{\text {ns }}$ & $4921,47^{*}$ & $4575,00^{\text {ns }}$ & $4178,81^{*}$ \\
& $(17,79)$ & $(15,15)$ & $(6,27)$ & $(13,46)$ & $(6,82)$ \\
\hline \multirow{2}{*}{ TTW } & $32,31^{*}$ & $7505,77^{\text {ns }}$ & $2355,46^{*}$ & $2019,48^{\text {ns }}$ & $2024,97^{*}$ \\
& $(35,61)$ & $(5,23)$ & $(6,33)$ & $(22,69)$ & $(12,19)$ \\
\hline
\end{tabular}

$\mathrm{UTM}=$ untreated teakwood; TTU = treated teakwood; $\mathrm{MOR}=$ modulus of rupture; $\mathrm{MOE}=$ modulus of elasticity; $\mathrm{ns}=$ no significant difference by the F-test at $5 \%$ confidence; * significant difference by the F-test at $5 \%$ confidence. Values between parentheses are the coefficients of variation of the samples.

The mechanical properties most affected by the heat treatment are MOR in flexural strength and impact flexion tests (Esteves and Pereira 2009). The reduction of these properties is related to the changes in the chemical structures of the wood (Yildiz et al. 2005). However, thermal treatments can increase the modulus of elasticity (Esteves and Pereira 2009).

There are two theories that explain the increase of the MOE. The first one affirms that the high temperature increases the crosslinks of lignin, improving the rigidity around cellulose microfibrils and the resistance of the lamella media (Gunduz et al. 2009). The second theory states that the increase in MOE is due to the increase in cellulose crystallinity and the reduction of equilibrium moisture (Esteves and Pereira 2009). In the present study, the thermal treatment provoked a 50\% reduction in MOR without significant increase of MOE.

The undesirable effect of thermal modifications the degradation of some mechanical properties, since the wood becomes more brittle with the deterioration of the amorphous polysaccharides (Esteves and Pereira 2009), causing a decrease in hardness (Unsal et al. 2003, Korkut 2008, Modes et al. 2017). In the present work, significant declines of hardness occurred in the longitudinal and tangential section. 


\section{Color measurements}

The heat treatment caused significant reductions in the blue-yellow color coordinate $(\mathrm{b} *)$, luminosity $(\mathrm{L})$, color saturation $(\mathrm{C} *)$ and hue angle $(\mathrm{h} *)$, but there was no significant change in the red-green chromatic coordinate $(\mathrm{a} *)$ (Table 4$)$. The total color variation $(\Delta \mathrm{E})$ was 24.11 .

For the untreated teakwood, the parameters $\mathrm{L}, \mathrm{a}^{*}$ and $\mathrm{b}^{*}$ were classified as pink color and for the treated wood the parameters were in the dark brown pattern (Camargos and Gonçalez 2001).

Table 4: Colorimetric parameters of wood.

\begin{tabular}{|c|c|c|c|c|c|}
\hline Treatment & $\mathrm{L}$ & $\mathrm{a}^{*}$ & $\mathrm{~b}^{*}$ & $\mathrm{C}^{*}$ & $\mathrm{~h}^{*}$ \\
\hline & $59,77^{*}$ & $9,59^{\mathrm{ns}}$ & $24,33^{*}$ & $26,17^{*}$ & $68,38^{*}$ \\
UTW & $(5,74)$ & $(8,70)$ & $(7,46)$ & $(5,60)$ & $(3,99)$ \\
\hline & $38,10^{*}$ & $9,81^{\mathrm{ns}}$ & $15,97^{*}$ & $18,87^{*}$ & $58,03^{*}$ \\
TTW & $(11,10)$ & $(14,54)$ & $(24,43)$ & $(21,72)$ & $(4,64)$ \\
\hline
\end{tabular}

$\mathrm{UTM}=$ untreated teakwood; TTU $=$ treated teakwood; $\mathrm{L}=$ brightness; $\mathrm{a} *=$ chromatic coordinate (green - red); $\mathrm{b} *=$ chromatic coordinate (blue - yellow); $\mathrm{C} *=$ color saturation; $\mathrm{h} *=$ hue angle; $\mathrm{ns}=$ non-significant difference by the $\mathrm{F}$-test at $5 \%$ confidence;

* significant difference by the F-test at $5 \%$ confidence. Values between parentheses are the coefficients of variation of the samples.

After the heat treatment, a significant reduction of $59.1 \%$ in the luminance $(\mathrm{L})$ was observed. This darkening has been described in similar studies of teakwood (Lopes et al. 2014, Méndez-Mejías and Moya 2016) and of other species (Esteves and Pereira 2009, Santos et al. 2014, Bonfatti Júnior and Lengowski 2018, Lengowski et al. 2018, Cetera et al. 2019). This loss of luminosity is caused by the chemical compounds resulting from the thermal degradation of hemicelluloses (Esteves and Pereira 2009). The decrease in the $b^{*}$ coordinate means that the heat treated wood has lower color saturation $(\mathrm{C} *)$ than the wood without heat treatment (Santos et al. 2014), and the hue angle $\left(\mathrm{h}^{*}\right)$ declines since this parameter is calculated as a function of the coordinates a $*$ and $b *($ ASTM 2016).

The total color change $(\Delta \mathrm{E})$ was 23,84 , considered very appreciable according to the classification proposed by Hikita et al. (2001), making the wood classification change from the pink color standard to the brown color of according to the wood color groups proposed by Camargos and Gonçalez (2001). These color changes in wood are attributed to the formation of colored compounds after the chemical reactions caused by the heat treatment (Chen et al. 2014, Lengowski et al. 2018, Cetera et al. 2019), as well as phenols (Cetera et al. 2019) and quinones (Tjeerdsma et al. 1998). Pratiwi et al. (2019) emphasizes a lower photodegradation in the color stability after the heat treatment of teakwood, this improvement being justified due to the increase of the lignin content formed by condensation during the heat treatment (Ayadi et al. 2013). 


\section{Thermal analysis}

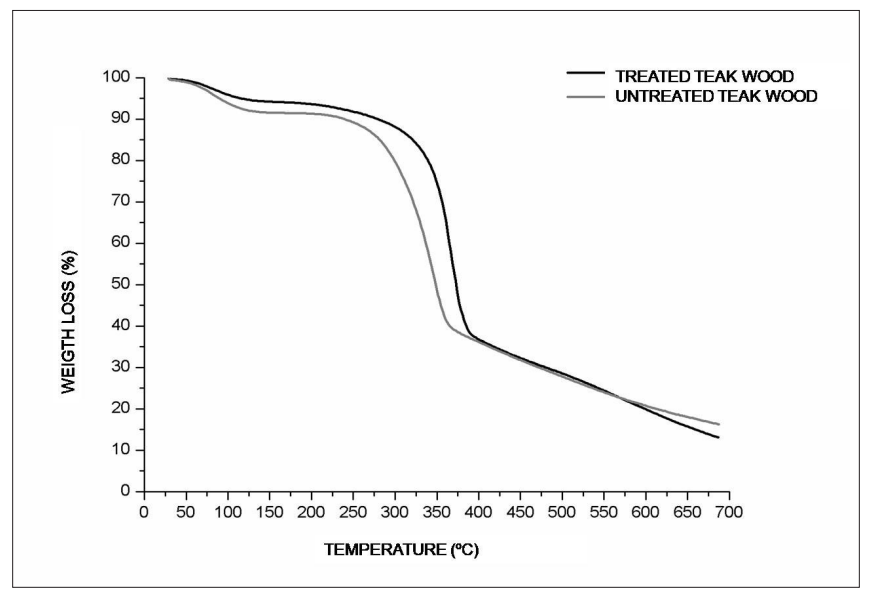

Figure 3: Weight loos of wood.

The thermal degradation of the wood can be divided into three temperature ranges. The first region $\left(100^{\circ} \mathrm{C}\right.$ to $200{ }^{\circ} \mathrm{C}$ ) is related to loss of water and extractives, as well as changes in chemical bonds; the second region $\left(200{ }^{\circ} \mathrm{C}\right.$ to $400{ }^{\circ} \mathrm{C}$ ), where the greatest decomposition of the macromolecular constituents of wood occurs; and the third region $\left(>400^{\circ} \mathrm{C}\right)$, where the complete degradation of the wood components occurs. A reduction in the initial temperature of the thermal degradation bands after the heat treatment of the wood was observed (Figure 3).

For treated teakwood, there was a lower initial weight loss (up to $200{ }^{\circ} \mathrm{C}$ ). In the range of $200{ }^{\circ} \mathrm{C}$ to 300 ${ }^{\circ} \mathrm{C}$, a lower weight loss was also observed for treated wood in relation to the control sample. In the range of $300{ }^{\circ} \mathrm{C}$ to $350{ }^{\circ} \mathrm{C}$, there was greater degradation of the wood without treatment, while in the range of $350{ }^{\circ} \mathrm{C}$ to $400{ }^{\circ} \mathrm{C}$ treated wood presented the greater degradation. The lowest weight loss for the untreated sample was also observed for the other degradation bands $\left(500^{\circ} \mathrm{C}\right.$ to $\left.700^{\circ} \mathrm{C}\right)$. Residual weight was high at $16,29 \%$ for the control sample and 13,08\% for treated wood (Table 5).

Table 5: Weight loss and residual weight of thermally treated teakwood wood.

\begin{tabular}{|c|c|c|c|c|c|c|c|c|c|}
\hline \multirow{3}{*}{ Treatment } & \multicolumn{7}{|c|}{ Mass loss (\%) at different temperature ranges $\left({ }^{\circ} \mathrm{C}\right)$} & Residual \\
\cline { 2 - 11 } & $25-$ & $100-$ & $200-$ & $300-$ & $350-$ & $400-$ & $500-$ & $600-$ & weight \\
& 100 & 200 & 300 & 350 & 400 & 500 & 600 & 700 & $(\%)$ \\
\hline UTW & 6,14 & 2,55 & 11,22 & 30,53 & 13,29 & 8,35 & 7,1 & 4,53 & 16,29 \\
\hline TTW & 4,11 & 2,26 & 5,34 & 12,79 & 38,53 & 8,28 & 8,65 & 6,96 & 13,08 \\
\hline
\end{tabular}

$\mathrm{UTM}=$ untreated teakwood; TTU $=$ treated teakwood.

The untreated sample had greater weight loss compared to the treated sample during the initial heating $\left(25^{\circ} \mathrm{C}\right.$ to $\left.100{ }^{\circ} \mathrm{C}\right)$. This temperature range is responsible for the evaporation of bound water in the cell wall, which is why the treated wood has less weight loss, since this modification makes the material less hydrophilic, and therefore less able to retain water.

Between $100{ }^{\circ} \mathrm{C}$ to $200{ }^{\circ} \mathrm{C}$, the temperature range where changes occur in the chemical bonds of the con- 
stituents of the wood and evaporation of extractives, there was low weight loss for both samples. Silva et al. (2019) and Pereira et al. (2013) also observed a small weight loss in this temperature range when investigating wood of Eucalyptus spp. by thermogravimetry.

The degradation of the hemicelluloses begins at $200^{\circ} \mathrm{C}$ (Sjöström 1981) and occurs up to $300^{\circ} \mathrm{C}$ (Poletto et al. 2012). Therefore, this temperature range is associated with loss of hemicelluloses and beginning of cellulose degradation. The lower weight loss for treated wood in this temperature range compared to untreated wood can be attributed to the previous degradation of the hemicelluloses and amorphous cellulose caused by the heat treatment.

In the range of $277^{\circ} \mathrm{C}$ to $397^{\circ} \mathrm{C}$, multiple stages of decomposition occur, such as dehydration and the formation of volatile components of cellulose (Ming et al. 2005, Wang et al. 2007). The loss of cellulose mass occurs after the degradation of hemicellulose, since the energy required for depolymerization of the cellulose chains is higher because it is semi-crystalline (Chaouch et al. 2012).

In both samples, the highest degradation occurred between $300{ }^{\circ} \mathrm{C}$ to $400{ }^{\circ} \mathrm{C}$, a range that characterizes cellulose degradation. Faster weight loss was observed between $200^{\circ} \mathrm{C}$ to $350{ }^{\circ} \mathrm{C}$ for wood without heat treatment. The possible cause of this difference is the high extractives content of the studied species and partial loss of these with the heat treatment. Wood with higher extractives content had accelerated thermal degradation compared to wood with lower extractive content (Poletto et al. 2012), due to the volatility of these compounds (Mészáros et al. 2007).

In the range of $350^{\circ} \mathrm{C}$ to $400{ }^{\circ} \mathrm{C}$, larger weight loss occurred for treated wood. This can be attributed to the predominance of crystalline cellulose after thermal treatment, where amorphous regions have already been partially eliminated, since the more organized the cellulose structure is, the more thermally stable wood is (Poletto et al. 2012).

Although it is the most thermally stable polymer, lignin does not have a specific degradation temperature, with rupture starting at $200{ }^{\circ} \mathrm{C}$ and continuing to $900{ }^{\circ} \mathrm{C}$ (Sjöström 1981, Wang et al. 2007, Pereira et al. 2013). The thermal resistance of lignin is linked to the type of precursor, where guaiacyl lignin is the most resistant to cleavage at high temperatures (Poletto et al. 2012).

\section{CONCLUSIONS}

The results of this study indicate that the heat treatment caused reduction of cell wall thickness, the formation of cross-fissures and the crystallization of the wax inside the pores. The volatilization of extractives and rupture of polysaccharides occurred, in which the hemicellulose was the macromolecular chemical component most affected. The equilibrium moisture, volumetric contraction, tangential contraction, contraction anisotropy, rupture modulus and longitudinal and tangential hardness were reduced after the heat treatment. The color previously classified as pink changed to dark brown. The thermal stability of the wood was improved by the heat treatment, which resulted in different behaviors between samples. In the untreated wood, the largest weight losses occurred between $25^{\circ} \mathrm{C}$ to $300{ }^{\circ} \mathrm{C}$ and $400{ }^{\circ} \mathrm{C}$ to $500{ }^{\circ} \mathrm{C}$, while after the heat treatment, the larg-est weight losses occurred between $350{ }^{\circ} \mathrm{C}$ to $400{ }^{\circ} \mathrm{C}$ and $500{ }^{\circ} \mathrm{C}$ to $700{ }^{\circ} \mathrm{C}$. Thermal treatment can be used in teakwood to improve physical properties and modify its colorimetric and thermal properties, adding value to this wood species.

\section{REFERENCES}

Ayadi, N.; Lejeune, F.; Charrier, F.; Charrier, B.; Merlin, A. 2013. Color stability of heat-treated wood during artificial weathering. Holz Roh Werkst 61(3): 221-226. https://doi.org/10.1007/s00107-003-0389-2

ASTM. 2014. Standard Test Methods for Small Clear Specimens of Timber. ASTM D-143-14. 2014. West Conshohocken, PA, USA. http://www.astm.org/cgi-bin/resolver.cgi?D143-14 
ASTM. 2016. Standard practice for calculation of color tolerances and color differences from instrumentally measured color coordinates. ASTM D-2244-16.2016. West Conshohocken, PA, USA. http://www.astm.org/cgi-bin/resolver.cgi?D2244-16

ASTM. 2017. Standard Test Methods for Density and Specific Gravity (Relative Density) of Wood and Wood-Based Materials. ASTM D-2395-17. 2017. West Conshohocken, PA, USA. http://www.astm.org/cgi-bin/resolver.cgi?D2395-17

Bonfatti Júnior, E.A.; Lengowski, E.C. 2018. Colorimetry applied to wood science and technology. Pesquisa Florestal Brasileira 38: 1-13. e201601394. https://doi.org/10.4336/2018.pfb.38e201601394

Bhuiyan, T.; Hirai, N. 2005. Study of crystalline behavior of heat-treated wood cellulose during treatments in water. J Wood Sci 51(1): 42-47. https://doi.org/10.1007/s10086-003-0615-x

Bonduelle, G.M.; Iwakiri, S.; Trianoski, R.; Prata, J.G.; Rocha, V.Y. 2015. Analysis of wood density and shrinkage of Tectona grandis wood in axial and radial direction of the tree trunk. Floresta 45(4): 671-680. http://dx.doi.org/10.5380/rf.v45i4.31991

Boonstra, M.J.; Van Acker, J.; Tjeerdsma, B.F.; Kegel, E.V. 2007.Strength properties of thermally modified softwoods and its relation to polymeric structural wood constituents. Ann For Sci 64(7): 679-690. https://doi.org/10.1051/forest:2007048

Boonstra, M.J.; Tjeerdsma, B. 2006.Chemical analysis of heat-treated softwoods. Holz Roh Werkst 64: 204-211.https://doi.org/10.1007/s00107-005-0078-4

Boonstra, M.J.; Rijsdijk, J.F.; Sander, C.; Kegel, E.V.; Tjeerdsma, B.; Militz, H.; Acker, J.V.; Stevens, M. 2006a. Microstructural and Physical aspects of heat-treated wood. Part 1. Softwoods. MaderasCienc Tecnol 8(3): 193-208.

Boonstra, M.J.; Rijsdijk, J.F.; Sander, C.; Kegel, E.V.; Tjeerdsma, B.; Militz, H.; Acker, J.V.; Stevens, M. 2006b Microstructural and physical aspects of heat treated wood. Part 2. Hardwoods. MaderasCienc Tecnol 8(3): 209-217. https://doi.org/10.4067/S0718-221X2006000300007

Camargos, J.A.A.; Gonçalez, J.C. 2001. A colorimetria aplicada como instrumento na elaboração de uma tabela de cores de madeira. Brasil Florestal 71: 30-41. https://core.ac.uk/download/pdf/33542076.pdf

Čekovská, H.; Gaff, M.; Makovická Osvaldová, L.M.; Kačík, F.; Kaplan, L.; Kubš, J. 2017. Tectonagrandis Linn. and its fire characteristics affected by its thermal modification of wood. BioResources 12(2): 2805-2817.https://bioresources.cnr.ncsu.edu/resources/tectona-grandis-linn-and-its-fire-characteristics-affected-by-its-thermal-modification-of-wood/

Cetera, P.; Russo, D.; Milella, L.; Todaro, L. 2019. Thermo-treatment affects Quercuscerris L. wood properties and the antioxidant activity and chemical composition of its by-product extracts. Ind Crops Prod 130: 380-388. https://doi.org/10.1016/j.indcrop.2018.12.099

Chagas, S.F.; Evangelista, W.V.; Silva, J.C.; Macedo, A.M.; Carvalho, L. 2014. Properties of teakwood of different ages coming from thinning. Brazilian Journal of Wood Science 5(2): 138-150. http://dx.doi.org/10.12953/2177-6830.v05n02a08

Chaouch, M.; Dumarçay, S.; Pétrissans, A.; Pétrissans, M.; Gérardin, P. 2012. Effect of heat treatment intensity on some conferred properties of different European softwood and hardwood species. Wood Sci Technol 47(4): 663-673. https://doi.org/10.1007/s00226-013-0533-z

Chen, Y.; Tshabalala, M.A.; Gao, J.; Stark, N.M.; Fan, Y. 2014. Color and surface chemistry changes of extracted wood flour after heating at $120{ }^{\circ} \mathrm{C}$. Wood Sci Technol 48 (1): 137-150. https://doi.org/10.1007/s00226-013-0582-3

Derkyi, N.S.A.; Bailleres, H.; Chaix, G.; Thevenon, M.F.; Oteng-Amoako, A.A.; Adu-Bredu, S. 2009. Colour variation in teak (Tectona grandis) wood from plantations across the ecological zones of Ghana. Ghana Journal of Forestry 25: 40-48. https://doi.org/10.4314/gjf.v25i1.60698 
Dias, A.C.C.; Marchesan, R.; Almeida, V.C.; Monteiro, T.C.; Moraes, C.B. 2018. Relationship between basic density and shrinkage in teca wood. Braz J Wood Sci 9(1): 37-44. http://dx.doi.org/10.12953/2177-6830/rcm.v9n1p37-44

Durlo, M.A.; Marchiori, J.N.C. 1992. Wood technology: retractability. Série Técnica, 10. CEPEF: Santa Maria, Brazil

Esteves, B.M.; Graça, J.; Pereira, H.M. 2008. Extractive composition and summative chemical analysis of thermally treated eucalypt wood. Holzforschung 62(3): 344-351. https://doi.org/10.1515/HF.2008.057

Esteves, B.M.; Pereira, H.M. 2009. Wood modification by heat treatment: A Review. BioResources 4(1): 370-404. https://ojs.cnr.ncsu.edu/index.php/BioRes/article/view/BioRes_04_1_\%23\%23\%23\%23_Esteves_P_Wood_Mod_Heat_Treatment

FAMATO. 2013. Diagnosis of Planted Forests in the State of Mato Grosso. IMEA: Brazil.

Fengel, D. 1966. On the changes of the wood and its components within the temperature range up to $200^{\circ} \mathrm{C}$ - Part 2. Holz Roh Werkst 24:98-109.

Gonçalvez, M.P.M.; Coffler, R.; Carvalho, A.M.; Garcia, R.A. 2007. Radial variation of basic density and fiber length of the wood of Tectona grandis L. Floram 14(1): 70-75. https://www.floram.org/article/588e2217e710ab87018b464c

Grinins, J.; Irbe, I.; Andersons, B.; Andersone, I.; Meija A.; Janberga, A.; Pavlovics, G.; Sansonetti, E. 2016. Thermo-hydro treated (THT) birch plywood with improved service properties. International Wood Products Journal 7(4): 181-187. https://doi.org/10.1080/20426445.2016.1212963

Gunduz, G.; Aydemir, D.; Karakas, G. 2009. The effects of thermal treatment on the mechanical properties of wild Pear (Pyrus elaeagnifolia Pall.) wood and changes in physical properties. Mater Des 30(10): 4391-4395.https://doi.org/10.1016/j.matdes.2009.04.005

Hamada, J.; Pétrissans, A.; Mothe, F.; Ruelle, J.; Pétrissans, M.; Gérardin, P. 2017. Intraspecific variation of european oak wood thermal stability according to radial position. Wood Sci Technol 51(4): 785794. https://doi.org/10.1007/s00226-017-0910-0

Hill, C. 2006. Wood Modification: Chemical, Thermal and Other Processes. Wiley: New York, NY, USA. https://doi.org/10.1002/0470021748

Hikita, Y.; Toyoda, T.; Azuma, M. 2001. Weathering testing of timber - discoloration. In High performance utilization of wood for outdoor uses: report on research project. Grant-in-Aid for Scientific Research. Inamura, Y (Ed.), Press-Net: Kyoto, Japan. p. 27-32.

IBÁ. 2019. Report 2019. IBÁ: Sao Paulo, Brazil. https://iba.org/datafiles/publicacoes/relatorios/iba-relatorioanual2019.pdf

Kokutse, A.D.; Bailleres, H.; Stokes, A.; Kokou, K. 2004. Proportion and quality of heartwood in togolese teak (Tectona grandis L.f.). Forest Ecol Manag 189(1-2): 37-48. https://doi.org/10.1016/j.foreco.2003.07.041

Kokutse, A.D.; Stokes, A.; Baillères, H.; Kokou, K.; Baudasse, C. 2006. Decay resistance of Togolese teak (Tectona grandis L. f) heartwood and relationship with colour. Trees 20(3): 219-223. https://doi.org/10.1007/s00468-005-0028-0

Korkut, S. 2008. The effects of heat treatment on some technological properties in Uludag fir (Abies bornmuellerinana Mattf.) wood. Build Environ 43(4): 422-428. https://doi.org/10.1016/j.buildenv.2007.01.004

Lemos, J.A.S.; Mendes, M.C.S.; Madi, J.P.S.; Pereira, B.L.C.; Oliveira, A.C. 2019. Influence of the propagation method on the production and quality of Tectona grandis wood. Advances in Forestry Science 6(3): 761-765. http://dx.doi.org/10.34062/afs.v6i3.8183

Lengowski, E.C.; Muniz, G.I.B.; Klock, U.; Nisgoski, S. 2018. Potential use of NIR and visible spectroscopy to analyze chemical properties of thermally treated wood. Maderas-Cienc Tecnol 20(4): 627-640. 
http://dx.doi.org/10.4067/S0718-221X2018005041001

Lengowski, E.C.; Muniz, G.I.B.; Nisgoski, S.; Magalhães, W.L.E. 2013. Cellulose acquirement evaluation methods with diferente degrees of crystallinity. Sci For 41(98): 185-194. https://www.ipef.br/publicacoes/ scientia/nr98/cap04.pdf

Lima, I.L.; Florsheim, S.M.B.; Longui, E.L. 2009. Influence of spacing on some physical properties of Tectona grandis Linn. f. Cerne 15(2): 244-250. http://cerne.ufla.br/site/index.php/CERNE/article/view/209

Lopes, J.O.; Garcia, R.A.; Nascimento, A.M.; Latorraca, J.V.F. 2014. Physical properties of heat-treated teak wood. Floram 21(4): 569-577. http://dx.doi.org/10.1590/2179-8087.040213

Méndez-Mejías, L.D.; Moya, R. 2016. Effects on density, shrinking, color changing and chemical surface analysis through FTIR of Tectona grandis thermo-treated. Sci For 44(122): 811- 820. http://dx.doi.org/10.18671/scifor.v44n112.03

Mészáros, E.; Jakab, E.; Várhegyi, G. 2007. TG/MS, PyGC/MS and THM-GC/MS study of the composition and thermal behavior of extractive components of Robinia pseudoacacia. J Anal Appl Pyrol 79(1-2): 61-70. https://doi.org/10.1016/j.jaap.2006.12.007

Ming, G.; Biaocan, L.; Shou Sheng, Y.; Min, Z. 2005. Flame retardance of wood treated with guanidine compounds characterized by thermal degradation behavior. J Anal Appl Pyrol 73(1): 151-156. https://doi.org/10.1016/j.jaap.2005.01.006

Modes, K.S.; Santini, E.J.; Vivian, M.A.; Haselein, C.R. 2017. Effect of heat treatment on mechanical properties of Pinus taeda and Eucalyptus grandis woods. Cienc Florest 27(1): 291-302. https://doi.org/10.5902/1980509826467

Mononen, K.; Alvila, L.; Pakkanen, T. 2002. CIELab measurements to determine the role of felling season, log storage and kiln drying on coloration of silver Birch wood. Scandinavian Journal Forest Research 17(2): 179-191. https://doi.org/10.1080/028275802753626827

Motta, J.P.; Alves, R.C.; Paes, J.B. 2010. Effect of heat treatment on the static flexural strength of wood Tectona grandis L.f. In II Simpósio de Ciência e Tecnologia da Madeira do Rio de Janeiro. Rio de Janeiro, Brazil.

Moya, R.; Berrocal, A.; Serrano, JR.; Tomazello, M. 2009. Variación radial de la anatomía, densidad y durabilidad de la Madera de teca (Tectona grandis) procedente de dos calidades de sitio y dos regiones climáticas de Costa Rica. Inv Agrar-Sist Rec F 18(2): 119-131

Niamké, F.B.; Amusant, N.; Charpentier, JP.; Chaix, G.; Baissac, Y.; Boutahar, N.; JayAllmand, C. 2011. Relationships between biochemical attributes (non-structural carbohydrates and phenolics) and natural durability against fungi in dry teakwood (Tectona grandis L. f.). Ann Forest Sci 68(1): 201-211. https://doi.org/10.1007/s13595-011-0021-2

Niamké, F.B.; Amusant, N.; Kadio, A.A.; Thevenon, MF.; Nourissier, S.; Adima, A.A.; Chaixh, G. 2014. Rapid prediction of phenolic compounds as chemical markers for the natural durability of teak (Tectona grandis Linn f.) heartwood by near infrared spectroscopy. J Near Infrared Spec 22(1): 35-43. https://doi.org/10.1255/jnirs.1091

Nocetti, M.; Rozenberg, P.; Chaix, G.; Macchioni, N. 2011. Provenance effect on the ring structure of teak (Tectona grandis L. f.) wood by X-ray microdensitometry. Ann Forest Sci 68(8): 1375-1383. https://doi.org/10.1007/s13595-011-0145-4

Nuopponen, M.; Vuorinen, T.; Jamsä, S.; Viitaniemi, P. 2005. Thermal modifications in softwood studied by FT-IR and UV resonance Raman spectroscopies. J Wood Chem Technol 24(1): 13-26. https://doi.org/10.1081/WCT-120035941

Ozsahin, S.; Murat, M. 2017. Prediction of equilibrium moisture content and 
specific gravity of heat treated wood by artificial neural networks. Eur J Wood Wood Prod 76(2): 563-572. https://doi.org/10.1007/s00107-017-1219-2

Pereira, B.L.C.; Carneiro, A.C.O.; Carvalho, A.M.M.L.; Trugilho, P.F.; Melo, I.C.N.A.; Oliveira, A.C. 2013. Study of thermal degradation of Eucalyptus wood by thermogravimetry and calorimetry. Rev Árvore 37(3): 567-576. https://doi.org/10.1590/S0100-67622013000300020

Poletto, M.; Zattera, A.J.; Santana, R.M.C. 2012. Thermal decomposition of wood: kinetics and degradation mechanisms. Bioresour Technol 126: 7-12. https://doi.org/10.1016/j.biortech.2012.08.133

Poncsák, S.; Kocaefe, D.; Bouazara, M.; Pichette, A. 2006. Effect of high temperature treatment on the mechanical properties of birch (Betula papyrifera). Wood Sci Technol 40(8): 647-663. https://doi.org/10.1007/s00226-006-0082-9

Pratiwi, L.A.; Darmawan, W.; Priadi, T.; George, B.; Merlin, A.; Gérardin, C.; Dumarçay,S.; Gérardin, P. 2019. Characterization of thermally modified short and long rotation teaks and the effects on coatings performance. Maderas-Cienc Tecnol 21(2):209-222. http://dx.doi.org/10.4067/S0718$221 \times 2019005000208$

Repellin, V.; Guyonnet, R. 2005. Evaluation of heat-treated wood swelling by differential scanning calorimetry in relation to chemical composition. Holzforschung 59(1): 28-34. https://doi.org/10.1515/HF.2005.005

Santos, D.V.B.; Moura, L.F.; Brito, J.O. 2014. Effect of heat treatment on color, weight loss, specific gravity and equilibrium moisture content of two low market valued tropical woods. Wood Res 59(2): 253-264.

Shi, J.; Lu, Y.; Zhang, Y.; Cai, L.; Shi, S. 2018. Effect of thermal treatment with water, $\mathrm{H}_{2} \mathrm{SO}_{4}$ and $\mathrm{NaOH}$ aqueous solution on color, cell wall and chemical structure of poplar wood. Sci Rep 8(1): 17735 . https://doi.org/10.1038/s41598-018-36086-9

Silva, E.J.; Cremonez, V.G.; Nisgoski, S. 2019. Color change and thermogravimetric analysis of thermally treated Eucalyptus grandis wood. Brazilian Journal of Wood Science 10(1): 39-47. https://doi. org/10.12953/2177-6830/rcm.v10n1p39-47 USA.

Sjöström, E. 1981. Wood Chemistry fundamentals and applications. Academic Press: New York, NY,

TAPPI. 2014. Sampling and preparing wood for analysis. TAPPI T 257 sp-14. 2014. Atlanta, GA, USA: TAPPI Press. https://www.tappi.org/content/sarg/t257.pdf

TAPPI. 2015. Acid-insoluble lignin in wood and pulp. TAPPI T $222 \mathrm{om}-15$. 2015. Atlanta, GA, USA: TAPPI Press. https://www.tappi.org/content/SARG/T222.pdf

TAPPI. 2017. Solvent extractives of wood and pulp. TAPPI T $204 \mathrm{~cm}-17$. 2017. Atlanta, GA, USA: TAPPI Press.

Tjeerdsma, B.; Boonstra, M.; Pizzi, A.; Tekely, P.; Militz, H. 1998. Characterization of thermally modified wood: molecular reasons for wood performance improvement. Holz Roh Werkst 56: 149-153 https://doi.org/10.1007/s001070050287

Tjeerdsma, B.; Militz, H. 2005. Chemical changes in hydroheat wood: FTIR analysis of combined hydroheat and dry heat-treated wood. Holz Roh Werkst 63(2): 102-111. http://dx.doi.org/10.4067/S0718$221 \times 2013005000020$

Unsal, O.; Korkut, S.; Atik, C. 2003. The effect of heat treatment on some properties and colour in eucalyptus (Eucalyptus camaldulensis Dehn.) wood. Maderas-Cienc Tecnol 5(2): 145-152. http://dx.doi.org/10.4067/S0718-221X2003000200006

Wang, S.; Liu, Q.; Luo, Z.; Wen, L.; Cen, K. 2007. Mechanism study on cellulose pyrolysis using thermogravimetric analysis coupled with infrared spectroscopy. Frontiers of Energy and Power Engineering 
in China 4(1): 413-419. https://doi.org/10.1007/s11708-007-0060-8

Weiland, J.; Guyonnet, R. 2003. Study of chemical modifications and fungi degradation of thermally modified wood using DRIFT spectroscopy. Holz Roh Werkst 61(3): 216-220. https://doi.org/10.1007/s00107-003-0364-y

Wheeler, E.; Baas, P.; Gasson, P. 1989. IAWA list of microscopic features for hardwood identification. IAWA Bulletin 10(3): 219-332. https://doi.org/10.1002/fedr.19901011106

Wikberg, H.; Maunu, S.L. 2004. Characterization of thermally modified hard and softwoods by ${ }^{13} \mathrm{C}$ CPMAS NMR. Carbohydr Polym 4(7): 461-466. https://doi.org/10.1016/j.carbpol.2004.08.008

Yildiz, U.C.; Yildiz, S.; Gezer, E.D. 2005.Mechanical and chemical behavior of beech wood modified by heat. Wood Fiber Sci 37(3): 456-461. https://wfs.swst.org/index.php/wfs/article/view/2034 